\title{
WORKING CAPITAL MANAGEMENT AND PROFITABILITY OF MANUFACTURING COMPANIES IN KOSOVO
}

\author{
Amant Fejzullahu* \\ Florije Govori**
}

Received: 23. 6. 2020

Professional paper

Accepted: 13. 12. 2021

UDC 339.137:330.101](497.115)

DOI https://doi.org/10.30924/mjcmi.26.2.16

\begin{abstract}
This article aims to demonstrate the profitability of the manufacturing companies in Kosovo impacted by the managing practices in the working capital. We use multiple regression analyses to estimate the effect of working capital indicators on profit. The Pearson correlation is used to calculate whether the variables are positively or negatively correlated and to what extent. The sample includes thirty-six manufacturing companies for the period 2012-2013. The data show that the increase in cash conversion cycle (CCC) and extension in the receivables term positively influenced operating profit and net return on
\end{abstract}

Abstract

\section{INTRODUCTION}

Capital management is a complex process of activities for manufacturing companies' management. It involves having the plan of capital employed in the projects and justifying the costs of these projects. Capital budgeting is integrated into the overall budgeting and the strategic plan. A few aspects of capital budgeting are associated with developing the operating budget. Meeting the goals set by the strategic plan through operational plans requires the use assets. On the contrary, the increase in payables days had a negative effect on the operating profit and the net return on assets. The rise in inventory days led to increased profit. Therefore, the companies' competitiveness is maintained mainly by extending trade credit terms to their customers and keeping the cash engaged longer in operating activities.

Keywords: financial performance, manufacturing companies, management, working $\mathrm{ca}$ pital, profitability.

of additional techniques for working capital management (WCM). The degree of the managing challenge is determined mainly by the country's economic and financial conditions.

Theoretically, companies can maximize their profits by maintaining their liquidity, i.e. correctly balancing short-term assets and debts. However, achieving this balance in practice is not simple. Even if the company initially achieved short-term balancing, maintaining it is more challenging due to

\footnotetext{
* Amant Fejzullahu, MSc, NewCo Switzerland SA, Chemin du Closel 5, 1029 Renens, Switzerland, Phone: +41 79 69683 57. E-mail: amant@newco.ch

** Florije Govori, PhD, assistant professor, Faculty of Economics, University of Prizren "Ukshin Hoti”, 1 Shkronjat, Prizren 20000, Kosovo, Phone: +383 44111 760, E-mail: florie.govori@gmail.com, ORCID: https://orcid. org/0000-0002-4237-8162
} 


\section{Journal of Contemporary Management Issues}

the influence of the various factors. In order to establish the right working capital policy, the management of the company needs to trace all factors that influence the working capital. Poor management of receivables, inventory, and payables can lead to the company's failure. Thus, their decisions on working capital play a crucial role in a company's profitability and liquidity. They need to trade-off between liquidity and profitability to maximize their value.

If a company tries to gain profit at the cost of liquidity, it may risk its solvency. Profits are important, but the company needs its liquidity to operate and meet its expenses and debts daily. If the company fails to meet the obligation, its reputation and creditworthiness score will be damaged. Company's inability to get financed or reach good credit terms with suppliers can lead to liquidation of its assets. On the other hand, the excess liquidity is not healthy because it shows that the company is not using its assets properly to create value. Instead, they are accumulating idle funds.

The fast recovery of receivables, the maintenance of the adequate inventory lev$\mathrm{el}$, and the replacement of the short-term financing from financial institutions that charge interest with suppliers that do not charge it, can all contribute to increasing the company's liquidity. However, the fast recovery of receivables can negatively affect the company's profit. Clients prefer to have a more extended payment due date. If competitors offer that, it can influence their decision to change the supplier. As a result, the company's sales will drop.

Keeping the inventory level as low as possible may generate unexpected costs in the case of an unforeseen increase in demand. In that case, the company pressures its suppliers to offer a longer deferred payment period. However, suppliers may increase the price or not offer special deals in the long term, which leads to the company's profit decline.

Therefore, companies focus on implementing a working capital policy that enables them to maintain their liquidity without compromising profitability. They aim to set a well-observed level of working capital at a calculated risk that enables profit generation.

Manufacturing is the main driver of economic and social development. Since Kosovo has experienced very slow progress in this regard, the sustainable and competing manufacturing sector is seen as a key to revitalizing the economy. In order to achieve that, the capital management techniques must be observed and the problems of Kosovo's manufacturing companies need to be understood. On the one hand, in the absence of a national economic development strategy, the country has a continuously negative balance of trade. On the other hand, the privatization process did not afford the expected economic development of the country. Several new owners of manufacturing companies have changed the activity by shifting from manufacturing to commercial and service activities.

As Kosovo has a comparative advantage in several types of goods, manufacturing has the potential to boost income, increase exports, and generate employment, as noticed by the World Bank (2017). However, this potential has been held back by wide regulatory and infrastructure gaps. Moreover, competitors' informality was found to be the main obstacle in Kosovo, followed by access to finance, corruption, crime, theft, and disorder. Similar causes were also indicated by the European Commission (EC). As the main barrier in improving the business environment, 
competition, and productivity of the economy, the EC (2014) stated the widespread informal economy, a weak rule of law, poor infrastructure, lack of access to finance, and lacking professional education.

Considering the above, it is necessary to analyze the behavior of companies in such a specific competing environment. As competition is influenced mainly by financial performance, we examined the relationship between working capital and profitability as primary indicators. Therefore, we investigated the effects of the accounts receivable, the effects of the inventory, the effects of the accounts payable, and the effects of the CCC on profitability indicators. This study is the first to examine the WCM and manufacturers' profitability in Kosovo.

\section{LITERATURE REVIEW}

The primary goal of every manufacturing company is to maximize profit and increase its market value. To achieve this, they analyze the forces that influence competition within an industry to create advantages over competitors, and consequently, improve their financial performance. The competitive performance demonstrates how the companies use their advantages in competition to boost financial performance. Depending on sector, activity, and market, companies use different indicators to measure their performance. In companies that operate in countries with underdeveloped financial markets WCM plays a crucial role in gaining competitive advantages by improving operational liquidity.

The working capital represents the difference between current assets and current liabilities. Current assets include all assets that the company can convert to cash within 12 months (cash in bank account, money that clients owe to the company, and inventory) while current liabilities include all debts that must be repaid within 12 months (debt owed to suppliers, debt toward financial institutions, accrued expenses for taxes, salary, and other operations).

The accounts receivable indicator measures how fast a company can collect debts from customers. In contrast, the accounts payable indicator gives the average number of days it takes the company to pay the debts to suppliers. The inventory indicator shows the pace at which a company can sell and replace inventory. CCC considers all these indicators, measuring the minimum days needed to turn short-term assets and liabilities into cash.

Regarding WCM, various studies have been provided by researchers. Some studies relate to the effects of WCM on profit, while others relate to working capital influence on providing and maintaining the firm's liquidity.

Deloof (2003) found an inverse relationship between the profitability and receivables, payables, and inventories on a sample of 1,009 firms. Lazaridis and Tryfonidis (2006) found an inverse association of the CCC with profit. Teruel and Solano (2007), in a sample of 8872 firms in Spain from 1996-2002, conclude that the company can raise profit by reducing the CCC. Samiloglu and Demirgunes (2008), using an example of manufacturing companies in the time span of ten years, found that profitability was negatively affected by the accounts receivable, leverage, and inventory. As for the relationship between growth in sales and profitability, results showed positive effects. Falope and Ajilore (2009) proved the same effect of WCM on firms' performance, regardless of their size. They found an inverse relation in net operating profit with the receivables, inventories, payables, and CCC. 


\section{Journal of Contemporary Management Issues}

In a sample consisting of 88 American manufacturing companies for three years, Gill et al. (2010) noticed an evident relationship between CCC and GOP. The authors indicate that managers generate profit for stockholders by decreasing the term in credit granted to their customers.

The study regarding the impact of WCM on firms' profit examined by Mathuva (2010) indicated that inventory conversion into sales and accounts payable was positively associated with profit. In contrast, the accounts receivable are associated negatively with profit. Sharma and Kumar (2011) considered the effects of WCM on the profit of companies in India. Their results showed a positive correlation of the WCM with profitability and an inverse correlation between the inventory and the accounts payable with profitability. The receivables and CCC positively correlated with profitability.

Baveld (2012) examined the WCM of Netherlands' public companies by observing them in the period of non-crisis and during the financial crisis, i.e. from 2004 to 2006, and from 2008 to 2009, respectively. Their results suggest that firms should not alter the working capital policy regarding payables and inventories in times of crisis in case they plan to increase profitability. The same cannot be said for accounts receivable due to the positive effect of receipts on next year's profit. DenčićMihajlov (2013) noticed that the impact of accounts receivable on the company's profit in Serbia changed during the financial crisis.

Knauer and Wöhrmann (2013) provide evidence on the positive impacts of receivables and inventories controlling in profit and reverse causality-driven impacts of payables controlling in profit. Makori and Jagongo's (2013) study about Kenyan manufacturing firms shows that the receivables and $\mathrm{CCC}$ increase negatively impacted the ROA. However, an increase in payables and inventories had a positive impact. The positive relation of inventory and payables with ROA was explained as the result of the fact that a high inventory level reduces the cost of a possible interruption in the production process and business loss, while the positive relation of payables with ROA may be due to good name created by the suppliers. While Korent and Orsag (2018) suggest that, when controlling for firms' features (size, age, revenue increase, etc.) and real GDP growth, WCM affects the firm's profit.

A positive relation between the $\mathrm{WCM}$ components and profitability is found in Pham et al. (2020) study. In contrast, CCC is inversely related with profitability. Authors justified these relations with specifics of the industry and the different stages of economic development associated with the economic management policies of the State.

Regarding the WCM practices, Morshed (2020) notes that working capital investment and financing policies substantially influence profitability. Since these policies are related to risk and return theory, the conservative policy reduces both the risk and return, while aggressive policy has the contrary impact. Lucia et al. (2021) found a negative relationship between inventory and payables with ROA and a positive relationship between receivables and $\mathrm{CCC}$ with ROA. According to the authors, the positive effect of CCC with ROA could be due to the reverse relationship of receivables and inventories with ROA that would be offset for in the CCC. Braimah et al. (2021) suggest that WCM significantly affects profitability, but each component of WCM represents a different influence. Therefore, each WCM component may guarantee a unique 
management strategy to maximize profitability. Further, the authors highlight managers' need to consider firm-specific features to formulate suitable WCM policies to help maximize profitability.

\section{METHODS}

Only the effects of working capital are considered in this study. The main reason for excluding the impact of the investment in fixed capital is that working capital is an important indicator of a company's operational liquidity regardless of its size. We use multiple regression analysis to study the impacts of WCM on the profitability of companies. The sample consists of thirtysix companies from five country districts for the period 2012-2013. This period was selected to create a comparative basis with the research results in other countries. Since there is yet no law in Kosovo that obliges SME companies to make their financial statements public, the study uses convenience sampling by including only the manufacturing companies willing to provide financial statements. The variables involved in the examination are grouped into the dependent variables, explanatory variables, and control variables (Table 1). Dependent variables include GOP and the net ROA, whereas the group of explanatory variables includes accounts receivable, accounts payable, inventory, and the CCC. The size, financial leverage, liquidity, and growth belong to the third group. The equations are as follows:

$$
\begin{aligned}
& \mathrm{GOP}=\beta 0+\beta 1 \mathrm{AR}+\beta 2 \mathrm{SIZE}+\beta 3 \mathrm{FL}+\beta 4 \mathrm{GROWTH}+\beta 5 \mathrm{LIQUIDITY}+\varepsilon \\
& \mathrm{ROA}=\beta 0+\beta 1 \mathrm{AR}+\beta 2 \mathrm{SIZE}+\beta 3 \mathrm{FL}+\beta 4 \mathrm{GROWTH}+\beta 5 \mathrm{LIQUIDITY}+\varepsilon \\
& \mathrm{GOP}=\beta 0+\beta 1 \mathrm{I}+\beta 2 \mathrm{SIZE}+\beta 3 \mathrm{FL}+\beta 4 \mathrm{GROWTH}+\beta 5 \mathrm{LIQUIDITY}+\varepsilon \\
& \mathrm{ROA}=\beta 0+\beta 1 \mathrm{I}+\beta 2 \mathrm{SIZE}+\beta 3 \mathrm{FL}+\beta 4 \mathrm{GROWTH}+\beta 5 \mathrm{LIQUIDITY}+\varepsilon \\
& \mathrm{GOP}=\beta 0+\beta 1 \mathrm{AP}+\beta 2 \mathrm{SIZE}+\beta 3 \mathrm{FL}+\beta 4 \mathrm{GROWTH}+\beta 5 \mathrm{LIQUIDITY}+\varepsilon \\
& \mathrm{ROA}=\beta 0+\beta 1 \mathrm{AP}+\beta 2 \mathrm{SIZE}+\beta 3 \mathrm{FL}+\beta 4 \mathrm{GROWTH}+\beta 5 \mathrm{LIQUIDITY}+\varepsilon \\
& \mathrm{GOP}=\beta 0+\beta 1 \mathrm{CCC}+\beta 2 \mathrm{SIZE}+\beta 3 \mathrm{FL}+\beta 4 \mathrm{GROWTH}+\beta 5 \mathrm{LIQUIDITY}+\varepsilon \\
& \mathrm{ROA}=\beta 0+\beta 1 \mathrm{CCC}+\beta 2 \mathrm{SIZE}+\beta 3 \mathrm{FL}+\beta 4 \mathrm{GROWTH}+\beta 5 \mathrm{LIQUIDITY}+\varepsilon
\end{aligned}
$$

where $\beta$ - represents the coefficients of independent variables that influence firm profitability, and $\varepsilon$ represents the errors of regression analysis.
We initially calculated the variables according to the mathematical model given in Table 1, and the average annual sales are standardized. Subsequently, the coefficients were processed using multiple regression models according to the equations above. 


\section{Journal of Contemporary Management Issues}

Table 1. Description and estimation of variables

\begin{tabular}{|c|c|c|}
\hline Variable & Description & Estimation \\
\hline \multicolumn{3}{|l|}{ Dependent variables } \\
\hline Gross operating profit - GOP & $\begin{array}{l}\text { This indicator represents the ratio } \\
\text { of the income before taxes, inter- } \\
\text { est, amortization, depreciation } \\
\text { (EBITDA), to the non-financial } \\
\text { assets. }\end{array}$ & $\begin{array}{l}\text { GOP = EBITDA / (Total assets - Finan- } \\
\text { cial assets) }\end{array}$ \\
\hline Return on assets & $\begin{array}{l}\text { ROA bases on the company's } \\
\text { earnings after interest and taxes. }\end{array}$ & ROA $=$ Net income $/$ Total assets \\
\hline \multicolumn{3}{|l|}{ Explanatory variables } \\
\hline Accounts receivable & $\begin{array}{l}\text { The average collection period } \\
\text { measures a company's effective- } \\
\text { ness in collecting its receivables. }\end{array}$ & $\mathrm{AR}=$ Accounts receivable $/($ Sales $/ 360)$ \\
\hline Inventory & $\begin{array}{l}\text { The days' sales of inventory used } \\
\text { to show the average period needed } \\
\text { for the company to sell its stocks. }\end{array}$ & $\mathrm{I}=$ Average inventory $/($ Sales / 360) \\
\hline Accounts payable & $\begin{array}{l}\text { The days' payable outstanding } \\
\text { used to measure the average period } \\
\text { the company pays its suppliers. }\end{array}$ & $\begin{array}{l}\text { AP = Accounts payable } /(\text { Cost of goods } \\
\text { sold / 360) }\end{array}$ \\
\hline $\mathrm{CCC}$ & $\begin{array}{l}\text { This indicator measures the period } \\
\text { it takes a company to convert } \\
\text { investments in inventory to cash. }\end{array}$ & $\mathrm{CCC}=\mathrm{AR}+\mathrm{I}-\mathrm{AP}$ \\
\hline \multicolumn{3}{|l|}{ Control variables } \\
\hline Size & The average sales. & $\begin{array}{l}\text { Size }=\text { Average sales of manufacturing } \\
\text { sector in Kosovo }\end{array}$ \\
\hline Financial leverage & $\begin{array}{l}\text { This indicator shows how much a } \\
\text { company relies on debt to finance } \\
\text { its assets. Since the effect of ac- } \\
\text { counts payable is calculated sepa- } \\
\text { rately in this study, these debts are } \\
\text { excluded from the formula. Hence, } \\
\text { the calculation is done considering } \\
\text { only the financial debt. }\end{array}$ & $\begin{array}{l}\mathrm{FL}=(\text { Total debt }- \text { accounts payable }) / \\
\text { Total assets }\end{array}$ \\
\hline Change in sales & $\begin{array}{l}\text { The growth ratio of the current } \\
\text { year's sales to those of the previ- } \\
\text { ous year. }\end{array}$ & $\begin{array}{l}\text { Growth }=(\text { Sales in } 2013-\text { Sales in 2012) } \\
\text { / Sales in } 2012\end{array}$ \\
\hline Liquidity indicator & $\begin{array}{l}\text { This indicator shows how the firm } \\
\text { covers its liabilities in the short } \\
\text { term. }\end{array}$ & $\begin{array}{l}\text { Liquidity = Current assets } / \text { Current } \\
\text { liability }\end{array}$ \\
\hline
\end{tabular}




\section{RESULTS AND DISCUSSION}

The research limitations, resulting from sampling methodology, relate to the small sample size, including only thirtysix manufacturing companies. Given that most businesses registered in the commercial register are family businesses with a limited workforce, not incorporating them in the research had little impact on the industry average and the relationship of variables. Nonetheless, the interpretation of the results and the conclusions do not relate to these businesses. Further research in this field should be based on the data of manufacturing companies obliged to publish their financial statements.

The average net return on total assets (ROA) in the manufacturing firms resulted in a rate of $8.04 \%$. Based on this indicator, the manufacturing sector shows a moderate performance on ROA. The average ratio of the income before taxes, interest, amortization, and depreciation (EBITDA) to the total value of the non-financial assets is $17.73 \%$. This average is satisfying while considering the denominator without financial assets.

Firms in Kosovo have a short period of receivables, with an average of 75.3 days. This average was shorter than in some countries in the region, as firms in Kosovo needed less than three months to collect receivables. In Turkey, the average was 139 (Samiloglu \& Demirgunes, 2008) and in Greece 148 (Lazaridis \& Tryfonidis, 2006). The average inventory turnover is 193 days, which is significantly long. This high average is due to the inability to predict the market situation because of large fluctuations in the delicate economic conditions. Moreover, wide distribution in the two publicly owned companies contributed to this high average.

The high average of 210 days in accounts payable shows the problems that firms in Kosovo face in the liquidity associated with the grown inventories and poor access to the financial market. As for the CCC, the average tells that firms require almost 58 days from the sale to collect accounts receivable and pay suppliers (Table 2 ).

Table 2. Descriptive statistics

\begin{tabular}{|l|c|c|c|c|c|}
\hline Variable & N & Mean & StDev & Min & Max \\
\hline ROA & 36 & 0.0804 & 0.0741 & -0.08 & 0.34 \\
\hline GOP & 36 & 0.1773 & 0.1838 & -0.04 & 1.15 \\
\hline Accounts receivable & 36 & 75.3 & 71.7 & 0 & 344.4 \\
\hline Accounts payable & 36 & 210.2 & 464.6 & 0 & 2844.5 \\
\hline Inventory & 36 & 193.2 & 133.3 & 8.6 & 842.5 \\
\hline CCC & 36 & 58.3 & 382.2 & -1937 & 692.4 \\
\hline Financial leverage & 36 & 0.3814 & 0.4176 & -0.07 & 2.66 \\
\hline Size (mil. $€$ ) & 36 & 184.7 & 305.8 & 6.6 & 1900 \\
\hline Liquidity indicator & 36 & 2.18 & 1.185 & 0.39 & 6.23 \\
\hline Change in sales & 36 & 0.0408 & 0.2006 & -0.6 & 0.57 \\
\hline
\end{tabular}

Source: Authors' calculations based on financial data of the manufacturing companies. 


\section{Journal of Contemporary Management Issues}

Results of the Pearson correlation show that receivables are positively associated with ROA. The increase in receivables is associated with an increase in ROA, with a coefficient of 0.147 . On the contrary, a weak negative correlation of -0.092 between debtors and GOP indicates a decrease in receivables associated with profit growth. Evaluation of the relationship between accounts payable and profit shows a significant positive association. The correlation with the ROA is 0.563 , and with GOP is 0.895 .

The profitability and inventory correlation are moderately positive. Coefficients for ROA and GOP are 0.601 and 0.774 , respectively. These results indicate that the increase in inventory is followed by increases in profit in the manufacturing sector. An influential factor in relation to inventory with profitability indicators may be the inflation rate fluctuations during the period observed (CBK, 2013; KAS, 2019a; KAS, 2019b; KAS, 2019c). The change in the inflation rate led to increased prices for many products where companies had generated revenue. Since the sample consists of $53 \%$ of companies focused on the food sector that is affected by inflation, the increase in profit could result from the price increase.

The correlation of the CCC with the two profitability indicators is negative. The coefficient of the relationship with GOP is -0.835 , indicating a strong negative correlation. The association of CCC with the ROA has a weaker negative strength than with GOP. The change in sales correlates positively with ROA and GOP, which confirms that as sales grow, profit increases. The size of the companies resulted in a positive correlation with profitability indicators which corroborates the results of previous studies (Lazaridis \& Tryfonidis, 2006; GarciaTeruel \& Martinez-Solano, 2007; Samiloglu \& Demirgunes, 2008; Gill et al., 2010). There is an insignificant low positive association of liquidity with GOP and a negative with ROA. As for financial leverage, the coefficients show a weak negative correlation with GOP and ROA (Table 3).

Table 3. Pearson correlations

\begin{tabular}{|l|l|l|l|l|l|l|l|l|l|}
\hline & ROA & GOP & Accounts & Accounts & Inventory & $\begin{array}{l}\text { Cash } \\
\text { conversion } \\
\text { cycle }\end{array}$ & $\begin{array}{l}\text { Financial } \\
\text { leverage }\end{array}$ & Size & Liquidity \\
\hline GOP & 0.671 & & & & & & & & \\
\hline Sig. & 0 & & & & & & & & \\
\hline $\begin{array}{l}\text { Accounts } \\
\text { receivable }\end{array}$ & 0.147 & -0.092 & & & & & & & \\
\hline Sig. & 0.392 & 0.594 & & & & & & & \\
\hline $\begin{array}{l}\text { Accounts } \\
\text { payable }\end{array}$ & 0.563 & 0.895 & -0.058 & & & & & & \\
\hline Sig. & 0 & 0 & 0.737 & & & & & & \\
\hline Inventory & 0.601 & 0.774 & 0.169 & 0.806 & & & & & \\
\hline Sig. & 0 & 0 & 0.326 & 0 & & & & & \\
\hline CCC & -0.447 & -0.835 & 0.317 & -0.946 & -0.599 & & & & \\
\hline Sig. & 0.006 & 0 & 0.06 & 0 & 0 & & & & \\
\hline
\end{tabular}




\begin{tabular}{|c|c|c|c|c|c|c|c|c|c|}
\hline $\begin{array}{l}\text { Financial } \\
\text { leverage }\end{array}$ & -0.054 & -0.219 & 0.648 & -0.23 & 0.059 & 0.421 & & & \\
\hline Sig. & 0.753 & 0.2 & 0 & 0.178 & 0.731 & 0.01 & & & \\
\hline Size & 0.634 & 0.955 & -0.123 & 0.948 & 0.799 & -0.896 & -0.239 & & \\
\hline Sig. & 0 & 0 & 0.475 & 0 & 0 & 0 & 0.161 & & \\
\hline $\begin{array}{l}\text { Liquidity } \\
\text { indicator }\end{array}$ & -0.153 & 0.157 & -0.253 & 0.039 & -0.04 & -0.109 & -0.198 & 0.053 & \\
\hline Sig. & 0.373 & 0.36 & 0.136 & 0.82 & 0.817 & 0.527 & 0.247 & 0.759 & \\
\hline $\begin{array}{l}\text { Change in } \\
\text { sales }\end{array}$ & 0.119 & 0.264 & 0.035 & 0.089 & 0.063 & -0.079 & 0.098 & 0.156 & 0.292 \\
\hline Sig. & 0.49 & 0.12 & 0.839 & 0.607 & 0.715 & 0.646 & 0.568 & 0.363 & 0.083 \\
\hline
\end{tabular}

Source: Authors' calculations based on financial data of the manufacturing companies.

Regression analysis regarding the ef- suggests that companies increased the GOP fects of receivables on the GOP indicates by extending the term in credit granted to that predictors explain $93.35 \%$ of GOP their customers (Table 4a, Table 4b).

changes. The positive beta coefficient

Table 4a. Summary of the model for GOP and autocorrelation indicator

\begin{tabular}{|c|c|c|c|c|}
\hline R-sq & R-sq(adj) & PRESS & R-sq(pred) & Durbin-Watson Statistic \\
\hline $93.35 \%$ & $92.24 \%$ & 0.171697 & $85.47 \%$ & 1.92187 \\
\hline
\end{tabular}

Table 4b. Regression results for interaction between accounts receivable and GOP

\begin{tabular}{|l|c|c|c|c|c|}
\hline Term & Coef & SE Coef & 95\% CI & P-Value & VIF \\
\hline Constant & 0.1358 & 0.0236 & $(0.0877 ; 0.1839)$ & 0 & \\
\hline Accounts receivable & 0.000151 & 0.000161 & $(-0.000178 ; 0.000480)$ & 0.355 & 1.78 \\
\hline Financial leverage & -0.0108 & 0.0282 & $(-0.0684 ; 0.0469)$ & 0.706 & 1.86 \\
\hline Size & 0.17227 & 0.00909 & $(0.15370 ; 0.19084)$ & 0 & 1.1 \\
\hline Liquidity indicator & 0.01412 & 0.00798 & $(-0.00218 ; 0.03041)$ & 0.087 & 1.19 \\
\hline Change in sales & 0.0832 & 0.0466 & $(-0.0120 ; 0.1785)$ & 0.084 & 1.17 \\
\hline
\end{tabular}

Source: Authors' calculations based on financial data of the manufacturing companies.

The variation in the ROA case is ex- in the credit term allowed to the buyers, the plained by about $47.93 \%$ of the predictor variables. The positive coefficient of reROA increases by 0.0256 euro (Table 5a, ceivables shows that for each extended day

Table 5b). 


\section{Journal of Contemporary Management Issues}

Table 5a. Summary of the model for ROA and autocorrelation indicator

\begin{tabular}{|c|c|c|c|c|}
\hline R-sq & R-sq(adj) & PRESS & R-sq(pred) & Durbin-Watson Statistic \\
\hline $47.93 \%$ & $39.25 \%$ & 0.241324 & $0.00 \%$ & 1.20736 \\
\hline
\end{tabular}

Table 5b. Regression results for the interaction between accounts receivable and ROA

\begin{tabular}{|l|c|c|c|c|c|}
\hline Term & Coef & SE Coef & 95\% CI & P-Value & VIF \\
\hline Constant & 0.0893 & 0.0266 & $(0.0350 ; 0.1436)$ & 0.002 & \\
\hline Accounts receivable & 0.000256 & 0.000182 & $(-0.000115 ; 0.000627)$ & 0.169 & 1.78 \\
\hline Financial leverage & -0.0181 & 0.0319 & $(-0.0831 ; 0.0469)$ & 0.574 & 1.86 \\
\hline Size & 0.0473 & 0.0103 & $(0.0263 ; 0.0682)$ & 0 & 1.1 \\
\hline Liquidity indicator & -0.01026 & 0.009 & $(-0.02865 ; 0.00812)$ & 0.263 & 1.19 \\
\hline Change in sales & 0.0253 & 0.0526 & $(-0.0822 ; 0.1328)$ & 0.635 & 1.17 \\
\hline
\end{tabular}

Source: Authors' calculations based on financial data of the manufacturing companies.

Based on the results above, receivables have the same effect on the two profitability indicators. The increase in receivables positively influenced the GOP and the ROA. A positive relationship of receivables with profitability is also found in previous literature. Sharma and Kumar (2011) relate the positive effect of receivables on profitability with the conditions and circumstances in which firms operate. The main factor that has influenced this relationship was competition. Lucia et al. (2021) justify this positive relationship by the specifics of the business. According to Denčić-Mihajlov (2013) it is crucial for firms to increase the level of receivables as they consider it profitable and beneficial.

In our study the positive relationship between receivables and profitability can be explained by the presence of strong competition of imported goods. In face of this competition, the manufacturing companies of Kosovo raise sales mainly by extending the payment period to their customers. This benefits the customers but also the companies by raising sales, which is diretly reflected on profitability. The extension of payment term implied the increase in the real costs of the funds of outstanding accounts receivable.
Although the increase in real costs has reduced net profit, no negative effect of receivables on the ROA was seen.

However, some companies have created a cycle where the initial balance is transmitted continuously over the years, while customers have made payments only for bills issued during the calendar year. This initial balance transfer caused the accumulation of receivables, funded from the company's profits, or worse, by short-term liabilities. Some receivables tend to become bad debt, a classification that could have direct consequences on the liquidity and equity of the company. Therefore, to avoid this risk, manufacturers must require the bank to provide guarantees from their customers. Similarly, as foreign suppliers, the companies should set the allowance limit with a payment deadline depending on the offered bank guarantee.

The inventory management results show that the change in GOP was $93.29 \%$, explained roughly by predictor variables. The beta coefficient is positive, indicating that an increase in this variable will increase manufacturing companies' profit (Table 6a, 
Table $6 \mathrm{~b}$ ). In the case of the ROA, about $46.17 \%$ of the variation is explained by the predictor variables. This percentage is low compared to the GOP. Even for this dependent variable, a positive coefficient is found. The coefficients show that an increase in inventory days increased the GOP by 0.0095 and the ROA by 0.0136 euro (Table 7a, Table 7b). This relationship supports some findings of the previous research. According to Matuva (2010), the high inventory level reduces the cost of supplying products and protects the firm against price fluctuations. Furthermore, the increase in inventory stocks avoids interruption in the production process. Similar positive relationship has been confirmed by Makori and Jangongo (2013), Gill et al.(2010), and Pham et al (2020). A positive effect of inventory on profitability was also found by Gill et al. (2010) and Pham et al. (2020).

Table 6a. Summary of the model for GOP and autocorrelation coefficient

\begin{tabular}{|c|c|c|c|c|}
\hline R-sq & R-sq(adj) & PRESS & R-sq(pred) & Durbin-Watson Statistic \\
\hline $93.29 \%$ & $92.17 \%$ & 0.172407 & $85.41 \%$ & 1.98925 \\
\hline
\end{tabular}

Table 6b. Regression results for the interaction between inventory and GOP

\begin{tabular}{|l|c|c|c|c|c|}
\hline Term & Coef & SE Coef & $\mathbf{9 5 \%}$ CI & P-Value & VIF \\
\hline Constant & 0.1282 & 0.0297 & $(0.0675 ; 0.1890)$ & 0 & \\
\hline Inventory & 0.000095 & 0.000122 & $(-0.000155 ; 0.000344)$ & 0.444 & 3.51 \\
\hline Financial leverage & -0.0029 & 0.0248 & $(-0.0536 ; 0.0479)$ & 0.909 & 1.42 \\
\hline Size & 0.1615 & 0.017 & $(0.1267 ; 0.1962)$ & 0 & 3.83 \\
\hline Liquidity indicator & 0.01292 & 0.00791 & $(-0.00323 ; 0.02908)$ & 0.113 & 1.16 \\
\hline Change in sales & 0.09 & 0.0476 & $(-0.0071 ; 0.1872)$ & 0.068 & 1.21 \\
\hline
\end{tabular}

Source: Authors' calculations based on financial data of the manufacturing companies.

Table 7a. Summary of the model for ROA and autocorrelation indicator

\begin{tabular}{|c|c|c|c|c|}
\hline R-sq & R-sq(adj) & PRESS & R-sq(pred) & Durbin-Watson Statistic \\
\hline $46.17 \%$ & $37.20 \%$ & 0.224681 & $0.00 \%$ & 1.28885 \\
\hline
\end{tabular}

Table 7b. Regression results for the interaction between inventory and ROA

\begin{tabular}{|l|l|l|l|l|l|}
\hline Term & Coef & SE Coef & $\mathbf{9 5 \% ~ C I ~}$ & P-Value & VIF \\
\hline Constant & 0.0805 & 0.034 & $(0.0112 ; 0.1499)$ & 0.024 & \\
\hline Inventory & 0.000136 & 0.00014 & $(-0.000149 ; 0.000421)$ & 0.339 & 3.51 \\
\hline Financial leverage & -0.0025 & 0.0284 & $(-0.0605 ; 0.0554)$ & 0.93 & 1.42 \\
\hline Size & 0.0319 & 0.0194 & $(-0.0077 ; 0.0716)$ & 0.111 & 3.83 \\
\hline Liquidity indicator & -0.01229 & 0.00903 & $(-0.03074 ; 0.00616)$ & 0.184 & 1.16 \\
\hline Change in sales & 0.0351 & 0.0543 & $(-0.0759 ; 0.1460)$ & 0.524 & 1.21 \\
\hline
\end{tabular}

Source: Authors' calculations based on financial data of the manufacturing companies. 


\section{Journal of Contemporary Management Issues}

The positive relation of inventory with profitability indicators can be explained with reference to transportation. Due to difficult transport circumstances, manufacturing firms were forced to maintain inventory stocks to reduce the high transport cost. Reserves in the inventory stock have enabled firms to continue the production process, which explains this positive relationship with profitability indicators. This relationship may also have been affected by inflation and raw material stock market fluctuations during this period.

However, improving road infrastructure should have a positive impact, as it enables new supply channels and better inventory management. Fast transport reduces the need for inventory accumulation. Furthermore, to avoid accumulation or shortage of inventories, the head of the production department must regularly coordinate with the sale and marketing department. As production managers are responsible for arranging the raw material, they must know if the company aims to launch any promotional campaigns that affect the immediate sales increase. Thus, inventory reductions will lead to low storage costs and increased profitability (Callioni, 2005; Hansen, et al., 2006; Preve \& SarriaAllende, 2010).

The evidence of payables' effects indicates that the predictors explain $93.17 \%$ of the GOP variation, which increased their relevance. The negative beta coefficient of accounts payable indicates that manufacturing companies that managed to reduce and keep to minimum accounts payable have increased the operating profit (Table $8 \mathrm{a}$, Table $8 \mathrm{~b})$. The coefficient of multiple determination shows that the independent variables explain roughly $45.74 \%$ of the ROA variations. The negative coefficient of accounts payable indicates that each day extended in the payables period decreases the ROA by 0.057 euro (Table 9a, Table 9b). Our findings support some evidence of a negative relationship between payables and profitability in the existing literature. Following Deloof (2003), Sharma and Kumar (2011) consider that less profitable firms tend to delay payments.

Table 8a. Summary of the model for GOP and autocorrelation indicator

\begin{tabular}{|c|c|c|c|c|}
\hline R-sq & R-sq(adj) & PRESS & R-sq(pred) & Durbin-Watson Statistic \\
\hline $93.17 \%$ & $92.03 \%$ & 0.179352 & $84.82 \%$ & 1.9464 \\
\hline
\end{tabular}

Table 8b. Regression results for the interaction between accounts payable and GOP

\begin{tabular}{|l|c|c|c|c|c|}
\hline Term & Coef & SE Coef & $\mathbf{9 5 \%}$ CI & P-Value & VIF \\
\hline Constant & 0.1469 & 0.0255 & $(0.0947 ; 0.1990)$ & 0 & \\
\hline Accounts payable & -0.000016 & 0.00006 & $(-0.000139 ; 0.000107)$ & 0.794 & 10.16 \\
\hline Financial leverage & 0.0057 & 0.0225 & $(-0.0403 ; 0.0517)$ & 0.802 & 1.15 \\
\hline Size & 0.1797 & 0.0283 & $(0.1218 ; 0.2376)$ & 0 & 10.44 \\
\hline Liquidity indicator & 0.01296 & 0.00798 & $(-0.00334 ; 0.02927)$ & 0.115 & 1.16 \\
\hline Change in sales & 0.0812 & 0.0481 & $(-0.0170 ; 0.1795)$ & 0.102 & 1.21 \\
\hline
\end{tabular}

Source: Authors' calculations based on financial data of the manufacturing companies. 
Table 9a. Summary of the model for ROA and autocorrelation indicator

\begin{tabular}{|c|c|c|c|c|}
\hline R-sq & R-sq(adj) & PRESS & R-sq(pred) & Durbin-Watson Statistic \\
\hline $45.74 \%$ & $36.69 \%$ & 0.174684 & $9.16 \%$ & 1.50074 \\
\hline
\end{tabular}

Table 9b. Regression results for the interaction between accounts payable and ROA

\begin{tabular}{|l|c|c|c|c|c|}
\hline Term & Coef & SE Coef & $\mathbf{9 5 \%}$ CI & P-Value & VIF \\
\hline Constant & 0.1143 & 0.029 & $(0.0549 ; 0.1736)$ & 0 & \\
\hline Accounts payable & -0.000057 & 0.000068 & $(-0.000197 ; 0.000083)$ & 0.411 & 10.16 \\
\hline Financial leverage & 0.01 & 0.0256 & $(-0.0423 ; 0.0623)$ & 0.698 & 1.15 \\
\hline Size & 0.0733 & 0.0322 & $(0.0075 ; 0.1391)$ & 0.03 & 10.44 \\
\hline Liquidity indicator & -0.01211 & 0.00907 & $(-0.03065 ; 0.00642)$ & 0.192 & 1.16 \\
\hline Change in sales & 0.0173 & 0.0547 & $(-0.0943 ; 0.1290)$ & 0.753 & 1.21 \\
\hline
\end{tabular}

Source: Authors' calculations based on financial data of the manufacturing companies.

Based on the results, the accounts payable negatively affects GOP and ROA. Several factors with business climate implications may have influenced these relationships. Companies that import raw materials were required to provide bank guarantees in the sum of payables to their suppliers. An increase in bank limit implied additional costs $(3 \%)$ for the company. A small number of companies, especially those importing from EU countries, have benefited from early payment discounts. To realize the bonus quota set by suppliers, firms provide a large part of supplies at the end of the year.

Many companies have made decisions without cost-benefit analysis, which affected the profit by increasing the cost of goods sold in the long term. Thus, they had not considered the indirect implications through in-depth analysis regarding strategic decisions that directly impact the competitive performance.

Engaged companies in the metalworking industry usually keep a low level of accounts payable to avoid implied losses from the volatility in the raw material prices. Easy and fast access to the financial market allows them to use short-term financing. Hence, given that the reduction in accounts payable increases the financial performance, companies in Kosovo should use short-term financing to benefit from the rebate granted by suppliers.

As for the impact of the CCC on GOP, the coefficient of multiple determination shows that $93.36 \%$ of variations can be explained by the predictor variables. The beta coefficient was positive, which means that increase of the CCC in manufacturing companies has resulted in increased profit (Table 10a, Table 10b). The multiple determination coefficient in the case of the ROA indicates that the predictors explain $50.31 \%$ of ROA. The positive beta coefficient indicates that an increase in the CCC has increased the ROA (Table 11a, Table 11b). Therefore, the CCC as an indicator of capital management shows the same effects on the dependent variables selected as profitability indicators. The results shows that the increase of CCC has positively affected the GOP and the ROA. Given that the working capital cycle is affected by the level of receivables, their positive relationship with profitability has influenced the relations 


\section{Journal of Contemporary Management Issues}

of CCC. The positive relationship of CCC with profitability has also been affected by the level of inventories. Our results regarding the positive relationship between CCC and profitability are similar to Gill et al. (2010), Sharma and Kumar (2011), and Lucia et al. (2021), who claim that CCC is affected by receivables, inventory, and payables.

Table 10a. Summary of the model for GOP and autocorrelation indicator

\begin{tabular}{|c|c|c|c|c|}
\hline R-sq & R-sq(adj) & PRESS & R-sq(pred) & Durbin-Watson Statistic \\
\hline $93.36 \%$ & $92.26 \%$ & 0.189229 & $83.99 \%$ & 1.96096 \\
\hline
\end{tabular}

Table 10b. Regression results for the interaction between CCC and GOP

\begin{tabular}{|l|c|c|c|c|c|}
\hline Term & Coef & SE Coef & $\mathbf{9 5 \%}$ CI & P-Value & VIF \\
\hline Constant & 0.1432 & 0.022 & $(0.0982 ; 0.1881)$ & 0 & \\
\hline CCC & 0.000058 & 0.000059 & $(-0.000062 ; 0.000177)$ & 0.333 & 6.72 \\
\hline Financial leverage & -0.0053 & 0.0248 & $(-0.0560 ; 0.0454)$ & 0.832 & 1.44 \\
\hline Size & 0.1914 & 0.0211 & $(0.1482 ; 0.2346)$ & 0 & 5.98 \\
\hline Liquidity indicator & 0.01358 & 0.00789 & $(-0.00254 ; 0.02970)$ & 0.096 & 1.17 \\
\hline Change in sales & 0.0788 & 0.0468 & $(-0.0169 ; 0.1744)$ & 0.103 & 1.18 \\
\hline
\end{tabular}

Source: Authors' calculations based on financial data of the manufacturing companies.

Table 11a. Summary of the model for ROA and autocorrelation

\begin{tabular}{|c|c|c|c|c|}
\hline R-sq & R-sq(adj) & PRESS & R-sq(pred) & Durbin-Watson Statistic \\
\hline $50.31 \%$ & $42.03 \%$ & 0.196344 & $0.00 \%$ & 1.553 \\
\hline
\end{tabular}

Table 11b. Regression results for the interaction between CCC and ROA

\begin{tabular}{|l|c|c|c|c|c|}
\hline Term & Coef & SE Coef & $\mathbf{9 5 \% ~ C I ~}$ & P-Value & VIF \\
\hline Constant & 0.1015 & 0.0243 & $(0.0519 ; 0.1512)$ & 0 & \\
\hline CCC & 0.000121 & 0.000065 & $(-0.000011 ; 0.000254)$ & 0.07 & 6.72 \\
\hline Financial leverage & -0.0134 & 0.0274 & $(-0.0693 ; 0.0425)$ & 0.628 & 1.44 \\
\hline Size & 0.0874 & 0.0233 & $(0.0398 ; 0.1351)$ & 0.001 & 5.98 \\
\hline Liquidity indicator & -0.0109 & 0.00871 & $(-0.02870 ; 0.00689)$ & 0.22 & 1.17 \\
\hline Change in sales & 0.0157 & 0.0517 & $(-0.0899 ; 0.1213)$ & 0.764 & 1.18 \\
\hline
\end{tabular}

Source: Authors' calculations based on financial data of the manufacturing companies.

Regardless of these relationships, companies in Kosovo should aim to approximate the time difference between bill payment and money collection from sales through the allowances with payment terms. They can improve liquidity indicators by decreasing inventories. By improving these indicators, companies will increase profitability.

Based on the overall outcomes, the following recommendations can enhance the 
managerial practices of manufacturing companies in Kosovo. First, most companies in Kosovo lack a sophisticated management accounting system (software) that would enable adequate management of daily operations ranging from planning to control, including WCM. A considerable part of the calculations on which the companies base their strategic decisions are made manually. They are prone to more data errors due to human errors. Therefore, these companies should invest in licensed specialized programs to better manage time and generate more accurate reports. Second, only a few manufacturing companies have hired specialized companies to conduct detailed market research that will serve as the basis for formulating the company's strategy. As a result of high information asymmetry, most companies in the country make wrong decisions during the planning process. These decisions directly affect the profitability of the company. Companies should conduct systematic research about the market and competition to avoid this problem.

\section{CONCLUSION}

In this paper, we have examined how the WCM techniques affect the profitability of manufacturers in Kosovo. The results indicate that lengthening $\mathrm{CCC}$ has positively impacted profitability. Moreover, the receivables had a positive effect on GOP and ROA. To face the competition from imported goods, companies mainly increased sales by extending the payment period to their customers. This extension positively affected the firms' profitability despite the real costs of funds of outstanding accounts receivable.

The average period needed to sell stocks has positively affected the GOP and ROA. The evidence shows that extension in inventory days has increased profitability. As for the accounts payable effect on the GOP and ROA, delaying the payments to suppliers resulted in a negative effect on profitability.

Therefore, the companies in Kosovo maintained and enhanced the financial performance mostly by extension in the payment term to their customers, which resulted in growth of sales, and by keeping the cash longer tied up in their operating activities.

\section{REFERENCES}

1. Anon. (2014). Kosovo Progress Report, Brussels: European Commission. https://ec.europa.eu/neighbourhoodenlargement/sites/near/files/pdf/ key_documents/2014/20141008-kosovo-progress-report_en.pdf.

2. Anon. (2017). Kosovo - Systematic Country Diagnostic (English), Washington, D.C. : World Bank Group. https://documents.worldbank.org/en/ publication/documents-reports/ documentdetail/282091494340650708/ kosovo-systematic-country-diagnostic

3. Baveld, M. (2012). Impact of Working Capital Management on the Profitability of Public Listed Firms in the Netherlands during the Financial Crisis. https://essay.utwente.nl/61524/

4. Braimah A, M. Y. Q. I. I. A. (2021). Working Capital Management and SMEs Profitability in Emerging Economies: The Ghanaian Case, SAGE Open, https://doi. org/10.1177/2158244021989317

5. Brealey, R. A., Myers, S. C. \& Allen, F. (2007). Principles of Corporate Finance. 6th Edition. Burr Ridge: McGraw-Hill Irwin. 


\section{Journal of Contemporary Management Issues}

6. Brealey, R. A., Myers, S. C. \& Marcus, A. J. (2001). Fundamentals of Corporate Finance. Burr Ridge: McGraw-Hill Irwin.

7. Callioni, G., de Montgros, X., Slagmulder, R., Van Wassenhove, L. N., \& Wright, L. (2005). Inventorydriven costs. Harvard Business Review, 83(3), 135-141.

8. CBK, 2013. Annual Report 2013, Prishtina: Central Bank of the Republic of Kosovo.

9. David, F. R., 2011. Strategic Management - Concepts and cases. Hoboken: Prentice Hall.

10. Defusco, R. A., McLeavey, D. W., Pinto, J. E. \& Runkle, D. E. (2001). Quantitative Methods for Investment Analysis. Charlottesville: CFA Institute.

11. Deloof, M. (2003). Does Working Capital Management Affects Profitability of Belgian Firms?. Journal of Business Finance \& Accounting, 30(3/4), 585, https://doi. org/10.1111/1468-5957.00008.

12. Denčić-Mihajlov, K. (2013). Impact of accounts receivables management on the profitability during the financial crisis: Evidence from Serbia. Proceedings of the 9th International Conference of ASECU "Systemic Economic Crises: Current Issues and Perspectives". Skopje: Northern Macedonia.

13. Fabozzi, F. J., Peterson, P. P. (2003). Financial Management \& Analysis. 2nd Edition. Hoboken: Wiley.

14. Falope, O. I., Ajilore, O. T. (2009). Working Capital Management and Corporate Profitability: Evidence from Panel Data Analysis of Selected Quoted Companies in Nigeria. Research Journal of Business Management, 3, 73-84, https://doi. org/10.3923/rjbm.2009.73.84.
15. Garcia-Teruel, J. P., Martinez-Solano, P. (2007). Effects of working capital management on SME profitability. International Journal of Managerial Finance, 3(2), 164-177. https://doi. org/10.1108/17439130710738718.

16. Gill, A., Biger, N. \& Mathur, N. (2010). The Relationship Between Working Capital Management and Profitability: Evidence From The United States. Business and Economics Journal, BEJ-10, 1-8 http://astonjournals.com/manuscripts/Vol2010/BEJ10_Vol2010.pdf

17. Hansen, D. R., Mowen, M. M., Guan, L. (2006). Cost Management Accounting and Control. 6th Edition. Mason: South-Western Cengage Learning.

18. Helfert, E. A. (2001). Financial Analysis: Tools and Techniques: A Guide for Managers. New York: McGraw-Hill.

19. Horcher, K. A. (2005). Essentials of Financial Risk Management. Hoboken: Wiley.

20. KAS (2019a). Import Price Index, Prishtina: Kosovo Agency of Statistics, https://ask.rks-gov.net/media/4819/impi-q1-2019.pdf

21. KAS (2019b). Producer Price Index, Prishtina: Kosovo Agency of Statistics, https://ask.rks-gov.net/ media/5032/i\%C3\%A7p-tm1-2019-anglisht-2.pdf

22. KAS (2019c). Consumer Price Index, Prishtina https://ask.rks-gov.net/media/4840/harmonised-indices-of-consumer-prices-hicp-may-2019.pdf

23. Knauer, T. \& Wohrmann, A. (2013). Working capital management and firm profitability. Journal of Management Control, 24(1), 77-87. 
24. Korent, D., Orsag, S. (2018). The Impact of Working Capital Management on Profitability of Croatian Software Companies. Zagreb International Review of Economics and Business, pp. 21(1), 47-65.

25. Larsen, E. J. (2003). Modern Advanced Accounting. 9th Edition. Burr Ridge:Irwin McGraw-Hill.

26. Lasher, W. R. (2005). Practical Financial Management. $4^{\text {th }}$ Edition. Mason: Thomson South-Western .

27. Lazaridis, I., Tryfonidis, D. (2006). Relationship between Working Capital Management and Profitability of Listed Companies in the Athens Stock Exchange. Journal of Financial Management and Analysis, 19 (1), 26-35.

28. Lucia, R. A., Sara, F. L., David, R. P. (2021). Impact of working capital management on profitability for Spanish fish canning companies. Marine Policy, 130, https://doi.org/10.1016/j. marpol.2021.104583

29. Makori, D. M., Jagongo, A. (2013). Working Capital Management and Firm Profitability: Empirical Evidence from Manufacturing and Construction Firms Listed on Nairobi Securities Exchange, Kenya. International Journal of Accounting and Taxation, 1(1), http://ijatnet.com/vol-1-no-1-december-2013-abstract-1-ijat

30. Marshall, D. H., McManus, W. W., Viele, D. F. (2011). Accounting- What the Numbers Mean. 9th Edition. Burr Ridge:McGraw-Hill Irwin.

31. Mathuva, D. M. (2010). The Influence of Working Capital Management Components on Corporate Profitability: A Survey on Kenyan Listed Firms. Research Journal of Business
Management, 4(1), 1-11. https://doi. org/10.3923/rjbm.2010.1.11.

32. Morshed, A. (2020). Role of working capital management in profitability considering the connection between accounting and finance. Asian Journal of Accounting Research, 5(2), 257-267.

33. Pham, K. X., Nguyen, Q. N., Nguyen, C. V. (2020). Effect of Working Capital Management on the Profitability of Steel Companies on Vietnam Stock Exchanges. Journal of Asian Finance, Economics and Business, 7(10), 741-750.

34. Preve, L. A., Sarria-Allende, V. (2010). Working Capital Management. Oxford: Oxford University Press.

35. Raiborn, C. A., Watson, S. F. (2003). Core Concepts of Accounting. Hoboken: Wiley.

36. Rakočević, S. B., Latinović, M., Milosavljević, M. (2014). The effects of working capital management on profitability in Serbia. In: Innovative Management and Firm Practice: An Interdisciplinary Approach. London: Palgrave Macmillan, 254-275.

37. Samiloglu, F. \& Demirgunes, K. (2008). The Effect of Working Capital Management on Firm Profitability: Evidence from Turke. The International Journal of Applied Economics and Finance, 2, 44-50 https://doi.org/10.3923/ijaef.2008.44.50.

38. Sharma, A. K. \& Kumar, S. (2011). Effect of Working Capital Management on Firm Profitability: Empirical Evidence from India. Global Business Review, 12(1), 159-173 https://doi. org/10.1177/097215091001200110 


\title{
Journal of Contemporary Management Issues
}

\author{
UPRAVLJANJE RADNIM KAPITALOM \\ I PROFITABILNOST \\ PROIZVODNIH PODUZEĆA NA KOSOVU
}

\begin{abstract}
Sažetak
U ovom se radu želi pokazati kako na konkurentske performanse proizvodnih poduzeća na Kosovu djeluju menadžerske prakse upravljanja radnim kapitalom. Kako bismo analizirali navedene performanse, koristimo Pearsonov korelacijski koeficijent $i$ multiplu regresiju za procjenu utjecaja indikatora radnog kapitala na dobit. U uzorak je uključeno 36 proizvodnih poduzeća, u periodu od 2012 do 2013 godine. Podaci pokazuju da se povećanje konverzijskog ciklusa gotovine i produženje potraživanja pozitivno odrazilo na operativni profit i neto povrat na imovinu. S druge strane, povećanje u danima realizacije obveza je imalo negativan efekt na operativu dobit i neto povrat na imovinu. Povećanje broja dana zaliha također je vodilo prema povećanoj dobiti, iz čega se može zaključiti da je konkurentnost bila zasnovana na produljenju trgovačkog kredita kupacima, kao i na angažmanu gotovine u operativnim aktivnostima.
\end{abstract}

Ključne riječi: konkurentske performanse, proizvodna poduzeća, menadžment, radni kapital, profitabilnost 